\title{
Farmers' perception and economic impact assessment of agromet advisory services in rainfed regions of Karnataka and Andhra Pradesh
}

\author{
RAVI DUPDAL ${ }^{1 *}$, RAJKUMAR DHAKAR ${ }^{2}$, C.A. RAMA RAO ${ }^{3}$, JOSILY SAMUEL ${ }^{3}$, B.M.K RAJU ${ }^{3}$, \\ P. VIJAYA KUMAR ${ }^{3}$ and V.U.M. RAO ${ }^{3}$
}

\author{
${ }^{1}$ ICAR-Indian Institute of Soil and Water Conservation, Research Centre, Ballari-583104 \\ ${ }^{2}$ ICAR-Indian Agricultural Research Institute, Pusa Campus, New Delhi-110012 \\ ${ }^{3}$ ICAR-Central Research Institute for Dryland Agriculture, Hyderabad-500059 \\ *Corresponding author: ravi.dupdal@gmail.com
}

\begin{abstract}
All India Coordinated Research Project on Agrometeorology (AICRPAM) of ICAR has started the micro-level Agromet Advisory Service (AAS) through its 25 cooperative centers across the country. Microlevel advisory based on weather forecast is the newer dimension of the AAS in the country. Studies on economic impact of these micro-level advisories are uncommon. Therefore, the present study was conducted using the field survey to assess the farmer's perception and economic impact of micro-level AAS in Vijayapura and Anantapur centers on pilot basis. Two groups i.e. AAS and non-AAS farmers, consisting of 40 farmers in each group were selected through multi-stage stratified random sampling technique. The probit regression model was employed to assess the factors influencing willingness to pay (WTP) for AAS. Majority of farmers (65\%) rated micro-level AAS as 'very good' on scale of 'very poor' to 'very good'. Majority of non-AAS farmers were aware about micro-level AAS but lagged in adopting the service. It needs further detailed investigation of underlying causes of not adopting the service. Farming experience, education, land holding size and income were found to be most important factors influencing the farmer's willingness for pay-based services. Results of economic impact revealed that there was 12 to 33 per cent increase in profit for AAS farmers as compared to non-AAS farmers.
\end{abstract}

Key words: Agromet Advisory Service, weather forecast, descriptive statistics, probit regression model, economic impact

Agriculture in India depends on weather and climatic conditions. Weather through various atmospheric factors plays a significant role in reaping good agricultural output (Bal and Minhas, 2017). Variable and uncertain weather is a pervasive fact that farmers have to cope up with it and this has bearing on the livelihoods of farmers. Lack of timely and reliable agrometeorological information is a serious limitation for effective farm planning operations (Prasad Rao and Manikandan, 2008). Weather forecasts are essential for taking decisions regarding crop choice, crop variety, sowing/ harvesting dates, and judicial management of agricultural operations such as seedbed preparations, ploughing, irrigation, scheduling and application of fertilizers, pesticide, herbicide and harvesting. In addition, timely weather information enables the farmers to plan their farm operations in way that not only minimize the cost and crop losses but also help in maximizing yield gains. Agriculturally relevant forecast is not only useful for efficient management of farm inputs but also leads to precise impact assessment (Gadgil, 1989). Hence, improved weather based Agromet Advisory
Service (AAS) greatly helps farmers to take advantage of favourable weather and mitigate the impacts of external weather situation. Agromet advisory services are vital tool which provide the valuable information for all types of agricultural operations associated with raising agricultural crops. Weather forecast and weather based agromet advisories help in increasing the economic benefit to the farmers with appropriate crop management practices (Ramachandrappa, 2018). The application of agromet advisory bulletin, based on real time weather forecast is a useful tool for enhancing the production and income of farmers (Ananta Vashisth, 2013).

The India Meteorological Department (IMD) has adopted AAS at district level since 2008. The district level AAS is provided to farmers to make use of medium range weather forecast information provided by National Centre for Medium Range Weather Forecasting (NCMRWF) and IMD. However, validity of such services disseminated to district level has some restrictions, particularly in view of 


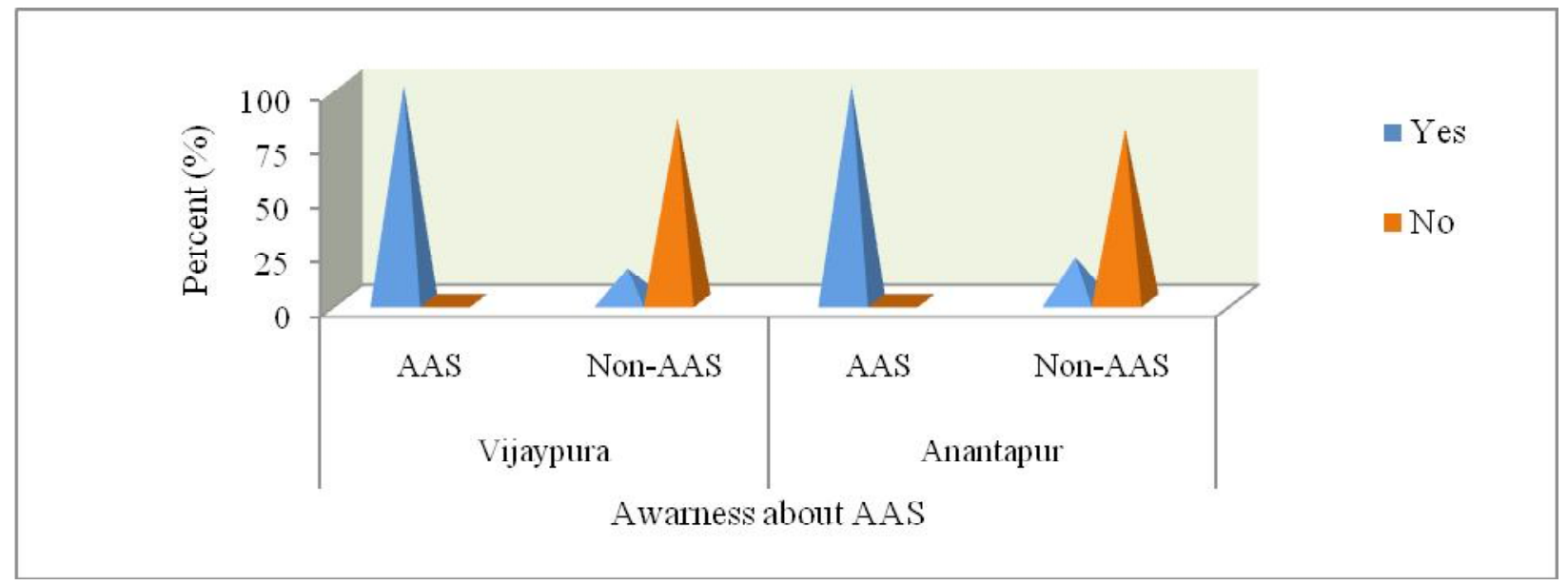

Fig. 1: Awareness about AAS services in study area

large variability in terms of crops, varieties and spatial weather anomalies at this level. Considering the variability of weather, climate and soil, the Central Research Institute for Dryland Agriculture (CRIDA), Hyderabad pioneered in starting flagship research programme of the Indian Council of Agricultural Research (ICAR) named "National Innovations in Climate Resilient Agriculture (NICRA)”. As part of this project, the All India Coordinated Research Project on Agrometeorology (AICRPAM) took up a pilot project during 2010 to develop and disseminate micro-level AAS through its 25 cooperating centers spread across the country towards enabling capacity building of farmers for climate resilience (Vijayakumar et al., 2017). The features of micro-level AAS include preparation and dissemination of weather advisories twice a week to farmers based on the forecasted weather data of IMD in consultation with KVK Subject Matter Specialists (SMS) and Field Information Facilitators (FIF) at village level. The Micro-level advisory based on weather forecast is the newer dimension of the agromet advisory services in the country. Studies on economic impact of these microlevel advisories are uncommon. Therefore, this study was conducted through field survey to assess the farmer's perception and economic impact of micro-level AAS in AICRPAM centers located at Vijayapura and Anantapur on pilot basis.

\section{MATERIALS AND METHODS}

The present study was based on primary data collected from farmers through a proper and pre-tested schedule. The multi-stage stratified random sampling technique was employed for selection of respondents. Districts to which AICRPAM centers were catering the first-stage of sampling unit and taluka within the district became the second stage of sampling unit. Villages within taluka were became third stage of sampling unit. Villages within taluka were divided into two groups viz., villages with AAS adoption and villages without AAS adoption for comparative study. The ultimate selection units i.e. farmers were divided into 3 groups (strata) based on size of land holding (small, medium and large). Out of 25 AICRPAM centers located across the country, Vijayapura and Anantapur centers were selected for present study. In Vijayapura centre, two villages namely Honawad as adopted and Aheri as non-adopted village were chosen for the study. In Anantapur centre, Pampanur as adopted and Papanpally as non-adopted village were chosen for the study. For the purpose of assessing the economic impact of agromet advisory service, 20 farmers each from AAS adopted and AAS non-adopted village were selected. The total sample size for present study was 80 out of which 40 are AAS adopters and 40 are AAS non-adopters. Further, care was also taken for selection of villages to ensure the similar socioeconomic condition and resource base in the villages for comparison purpose.

The descriptive statistics like frequency, percentage and tabular analysis were employed to assess the farmer's awareness, perception and economic impact of AAS services. The crop yields information both under kharif and rabi season along with input usage of both AAS and non-AAS farmers was collected and complied for the study. Probit regression model was employed to assess the factors responsible for willingness to pay for AAS service.

\section{Probit regression model}

In this study, we aimed to estimate the farmers willingness to pay (WTP) for AAS and factors affecting the decision of farmer. The probit regression model is a statistical probability model with two categories (yes/no) in the 
dependent variable and it is based on the cumulative normal probability distribution. In the binary probit model, willingness to pay was taken as 'one', while unwillingness to pay as 'zero'. The independent variables considered in the study were age of the farmers, family size, education, farming experience, land holding size, income and gender of the farmers.

\section{Probit regression model was presented as follows;}

$\mathrm{WTP}=\mathrm{b}_{0}+\mathrm{b}_{1} \mathrm{X}_{1}+\mathrm{b}_{2} \mathrm{X}_{2}+\mathrm{b}_{3} \mathrm{X}_{3}+\mathrm{b}_{4} \mathrm{X}_{4}+\mathrm{b}_{5} \mathrm{X}_{5}+\mathrm{b}_{6} \mathrm{X}_{6}+\mathrm{b}_{7} \mathrm{X}_{7}+$ $\mathrm{e}_{\mathrm{i}}$

Where,

$b_{0}=$ Intercept, $\mathrm{X}_{1}=$ Age of the sample farmers in (years), $X_{2}=$ Size of the family in (numbers), $X_{3}=$ Dummy variable for education level (educated $=1$, not educated $=2$ ), $\mathrm{X}_{4}=$ Farming experience (years), $\mathrm{X}_{5}=$ Land holding size (ha), $\mathrm{X}_{6}=$ Level of income in percentage, $\mathrm{X}_{7}=$ Dummy variable for gender $($ male $=1$, female $=2), e_{i}=$ Error term

\section{RESULTS AND DISCUSSION}

\section{Socio-economic characteristic of $A A S$ and non-AAS farmers}

The socio-economic characteristics of the farm households are assumed to have differential impact on a farmers' perception about agromet advisory service and his/ her capacity to adopt it (Table 1). The results revealed that $50 \%$ of AAS farmers are in old aged groups while $45 \%$ of nonAAS farmers are in the middle aged groups. The age of farmers usually represents his experience in farming and old aged farmers are expected to have high experience and knowledge about farming and associated risks. They also perceived larger climatic variability and its impact on crop yields as compared to younger farmers. The results are in line with findings of Preethi et al. (2013) and Dhanya and Ramachandran (2016). The education of farmers has important implication on technology adoption and its usage. The higher level of education among farmers help in access to more advanced technology and information. Nearly onethird of AAS farmers were illiterates while more than half of the non-AAS farmers were illiterates. More than half of AAS farmers possessed higher secondary education while only one-third of non-AAS farmers possessed higher secondary education. Only five per cent of non-AAS farmers attained graduation while $10 \%$ of AAS farmers attained graduation in the study area. The results are in line with findings of Dhamodaran and Vasanth Kumar (2001). Farming experience was higher in case of AAS farmers (52.5\%) as compared to that of non-AAS farmers (45\%). AAS farmers had marginally less access to irrigation water (17.5\%) in comparison to nonAAS farmers (22.5\%). Thus, farmers with agromet advisory services judiciously conserve and utilized water for critical life saving irrigations as compared to non-AAS farmers. Agriculture was the main source of income for more than $50 \%$ of both AAS and non-AAS farmers in the study area. Less than half of farmers in both categories were engaged in off-farm employment for alternative source of income. In both AAS as well as non-AAS group female participation in agricultural activities was low as compared to male participation.

\section{Awareness about A AS service in study area}

The results of farmer's awareness about agromet advisory services in two AICRPAM centers i.e. Vijayapura and Anantapur are shown in Fig. 1. The interesting observation was that even majority of non-AAS farmers (80$85 \%$ ) in both the centers had awareness about the service but lagged in the adoption of the service. Only $15-20 \%$ of non-AAS farmers were not aware about the service. Among two centers, the awareness was higher in Vijayapura compared to Anantapur centre. Awareness about agromet advisory service was hundred percent in AAS adopted villages of the both centers. The non-AAS farmers received information from various mass media like radio, television and from fellow friends in the village however they are not following agromet advisories issued by AICRPAM centers since more than $50 \%$ of non AAS farmers are illiterate and not able to read and write.

\section{Sources of AAS Information to farmers}

The agromet advisories were disseminated to farmers through various modes of communication like radio, television, mobile phones, newspaper and AAS bulletin in printed form/public notice (Table 2). Among the different modes of communications, nearly $85 \%$ of farmers accessed the AAS advisories through mobile phones followed by printed AAS bulletins (70\%). However, the information received through personal contact was limited to $20-25 \%$ of farmers. The results are in line with findings of Ramachandrappa etal. (2018).

\section{AAS farmer's perception towards agromet advisory service in study centers}

The results on farmers' perception about agromet advisory service revealed that $65 \%$ of farmers rated the service as 'very good' on the scale of very poor to very good (Table 3). Majority of farmers ( $>90 \%$ ) agreed on essentiality of AAS and felt that advisories based on predicted rainfall 
Table 1: Socio-economic characteristics of farm households in study area

\begin{tabular}{|c|c|c|c|c|c|c|}
\hline \multirow[t]{2}{*}{ S.No. } & \multirow[t]{2}{*}{ Particulars } & \multirow[t]{2}{*}{ Category } & \multicolumn{2}{|c|}{ AAS Farmers $(n=40)$} & \multicolumn{2}{|c|}{ Non-AAS Farmers $(n=40)$} \\
\hline & & & $f$ & $\%$ & $f$ & $\%$ \\
\hline \multirow[t]{3}{*}{1.} & \multirow[t]{3}{*}{ Age } & Young $(<35)$ & 06 & 15 & 14 & 35 \\
\hline & & Middle (36-45) & 14 & 35 & 18 & 45 \\
\hline & & $\operatorname{Old}(>46)$ & 20 & 50 & 08 & 20 \\
\hline \multirow[t]{4}{*}{2.} & \multirow[t]{4}{*}{ Education } & Illiterate & 07 & 15 & 21 & 52.5 \\
\hline & & Primary & 20 & 50 & 11 & 27.5 \\
\hline & & Higher secondary & 09 & 25 & 06 & 15 \\
\hline & & Graduation & 04 & 10 & 02 & 05 \\
\hline \multirow[t]{2}{*}{3.} & \multirow[t]{2}{*}{ Gender } & Male & 35 & 87.5 & 27 & 67.5 \\
\hline & & Female & 05 & 12.5 & 13 & 32.5 \\
\hline \multirow[t]{3}{*}{4.} & \multirow[t]{3}{*}{ Family size } & Small (up to 5) & 17 & 42.5 & 09 & 22.5 \\
\hline & & Medium (6 to 8$)$ & 18 & 45 & 18 & 45 \\
\hline & & Large $(>9)$ & 05 & 12.5 & 13 & 32.5 \\
\hline \multirow[t]{2}{*}{5.} & \multirow[t]{2}{*}{ Family type } & Nuclear family & 28 & 70 & 24 & 60 \\
\hline & & Joint family & 12 & 30 & 16 & 40 \\
\hline \multirow[t]{3}{*}{6.} & \multirow{3}{*}{$\begin{array}{l}\text { Farming } \\
\text { experience }\end{array}$} & Low (up to 15 years) & 07 & 17.5 & 11 & 27.5 \\
\hline & & Middle (16-25 years) & 12 & 305 & 18 & 45 \\
\hline & & $\operatorname{High}(>25$ years $)$ & 21 & 2.5 & 11 & 27.5 \\
\hline \multirow[t]{2}{*}{7.} & \multirow{2}{*}{$\begin{array}{l}\text { Social } \\
\text { participation }\end{array}$} & Yes & 08 & 20 & 06 & 15 \\
\hline & & No & 32 & 80 & 34 & 85 \\
\hline \multirow[t]{3}{*}{8.} & \multirow{3}{*}{$\begin{array}{l}\text { Land holding } \\
\text { (ha) }\end{array}$} & Marginal \& small & 06 & 15 & 15 & 37.5 \\
\hline & & Medium & 16 & 40 & 17 & 42.5 \\
\hline & & Large & 18 & 45 & 08 & 20 \\
\hline \multirow[t]{2}{*}{9.} & \multirow{2}{*}{$\begin{array}{l}\text { Access to } \\
\text { irrigation }\end{array}$} & Yes & 07 & 17.5 & 09 & 22.5 \\
\hline & & No & 33 & 82.5 & 31 & 77.5 \\
\hline \multirow[t]{3}{*}{10.} & \multirow{3}{*}{$\begin{array}{l}\text { Farmers } \\
\text { income }\end{array}$} & Less than 50,000 & 10 & 25 & 13 & 32.5 \\
\hline & & $50,000-100,000$ & 13 & 32.5 & 07 & 17.5 \\
\hline & & Above 100,000 & 17 & 42.5 & 20 & 50 \\
\hline \multirow[t]{2}{*}{11.} & \multirow{2}{*}{$\begin{array}{l}\text { Off-farm } \\
\text { occupation }\end{array}$} & Yes & 18 & 45 & 16 & 40 \\
\hline & & No & 22 & 55 & 24 & 60 \\
\hline
\end{tabular}

Source: Field survey data.

event is very much useful in their farming activities followed by advisories based on the temperature. These results are in conformity with studies of Vernon (1994) and Maddison (2006). Majority ( $85 \%$ ) of farmers perceived that AAS was essential and it helps to reduce the cost of cultivation in agricultural production followed by managing pest and diseases (75\%) during cropping season. More than $80 \%$ of farmers opined that real time agromet advisory service was helpful in sowing stage since dissemination of AAS services prior to cropping season with useful weather information particularly information on timely rainfall, temperature and humidity helps farmers to plan their farm activities particularly land preparation and sowing activities timely and accurately. More than $75 \%$ of farmers perceived that micro-level AAS disseminated through AICRPAM centers was accurate, timely available and more than $80 \%$ of farmers opined that biweekly forecast information was good as it is helps to take short term decision on farming activities. Further, farmers willingness to pay for AAS indicates that less than half (40$45 \%$ ) of farmers presently willing for pay based services. Findings from study also indicated that more than $85 \%$ of AAS farmers were satisfied with micro-level AAS. 
Table 2: Source of AAS information to farmers

\begin{tabular}{llll}
\hline S.No. & Particulars & $\begin{array}{l}\text { Vijayapura } \\
\text { centre (\%) }\end{array}$ & $\begin{array}{l}\text { Anantapur } \\
\text { centre (\%) }\end{array}$ \\
\hline 1. & Radio & 10 & 15 \\
2. & TV & 25 & 35 \\
3. & Mobile & 85 & 85 \\
4. & News paper & 60 & 45 \\
5. & AAS bulletin & 70 & 70 \\
6. & Personal contact & 20 & 25 \\
\hline
\end{tabular}

Source: Field survey data.

\section{Factors determining farmer's willingness-to-pay (WTP) for AAS service}

Analysis of factors affecting WTP for the AAS service through probit regression model showed that farming experience, land holding size and income level were the important factors in Vijayapura centre (Table 4). Land holding size and income level positively affected WTP for the services as evident from significant positive coefficient (slope) of regression model, whereas farming experience showed significant negative response. The land holding size and income level demonstrating one to one relationship which denotes that higher the size of land holding and income level of the farmers, higher will be the WTP for service while experience of the farmers shows reciprocal relationship which indicate that higher the experience of the farmers, lower will be his willing to pay for the service because farmer use his own experience in farming rather than paying to the service.

At Anantapur centre, farming experience and education level determined willingness to pay for AAS services. Regression coefficient for level of education was positive and significant whereas farming experience was significantly negative at $p<0.05$. The positive relation of education level implied that higher the education level and knowledge of farmers, higher will be his WTP for the service. At present $85 \%$ of AAS farmers satisfied with advisory service disseminated byAICRPAM centre but most of them were not willing to pay for the services since most of them cultivated rainfed crops with poor and limited farm resources.

\section{Economic impact of AAS on crop productivity and economics of cropping system}

The economic impact studies indicated that there were considerable benefits to farmers who adopted and regularly follow the agromet advisory services over non- adopted farmers. The percent gain in income due to AAS was ranging from 12 to 33 per cent (Table 5). The net returns realized byAAS farmers was more as compared to non-AAS farmers which was mainly attributed to timely adoption of farm advisories disseminated by AICRPAM centers. Further, better crop management practices based on advisories such as timely sowing, selection of improved crop cultivar, timely application of fertilizer, pest and disease management, life saving irrigation and harvesting which helps them to reduce the cost of production over non-AAS farmers. The high returns and reduced cost of different crops under AAS category was also evident from the benefit cost ratios arrived from the results. The yield of maize, groundnut, rabi sorghum and castor+redgram crop increased to the tune of 3, 1.5, 1 and $2+0.5 \mathrm{q} \mathrm{ha}^{-1}$ respectively for AAS adopted farmers as compared to non-AAS farmers in study area. The increase in crop yields in case of AAS farmers was also due to judicious use of farm inputs based on the real time agromet advisories. Chaudhari et al. (2010) reported that the per cent increase in yield due to adoption of agromet advisory bulletins prepared based on medium range weather forecast by NCMRWF was 13-15 q ha-1 in rice, $10 \mathrm{q} \mathrm{ha}^{-1}$ in mango and cashew nut in high rainfall zone of Konkan in Maharashtra. Ananta Vashisth et al. (2013) reported that weather based crop management practices which includes timely land preparation and sowing, adoption of recommended seed rate and suitable crop cultivars, timely weeding, in-situ moisture conservation measures like furrow between paired rows of redgram to conserve rainwater and maintain the soil moisture, pesticide application, irrigation and harvesting which helped in realizing higher yield of finger millet and groundnut cropping system. Rajegowda et al. (2008) reported that in the Eastern dry zone of Karnataka the farmers who adopted the agromet advisories have realized an average economic benefit of 31.4, 24.7, 16.2 and $20.6 \%$ in finger millet, redgram, field bean and tomato, respectively.

\section{CONCLUSION}

The present study revealed that micro-level agromet advisory service played an important role in improving the agricultural production and farm income. The farmer's perception towards agromet advisory services issued by AICRPAM centers was very good and positive among AAS farmers. At present, farmer's willingness to pay for AAS was low since most of farmers want to use advisory service at free of cost due to their farm resource constraints. There were considerable economic benefits to farmers who adopted farm advisories issued by AICRPAM centers regularly as 
Table 3: AAS farmer's perception towards agro-met advisory service in study centers

S.No. Farmers $\quad$ Vijayapura centre Anantapurcentre

\begin{tabular}{|c|c|c|c|c|c|}
\hline & perception & $f$ & $\%$ & $f$ & $\%$ \\
\hline \multirow[t]{5}{*}{$\overline{1 .}$} & Perception about AAS & & & & \\
\hline & Very poor & 01 & 05.00 & 02 & 10.00 \\
\hline & Poor & 04 & 20.00 & 05 & 25.00 \\
\hline & Good & 02 & 10.00 & 00 & 00.00 \\
\hline & Very good & 13 & 65.00 & 13 & 65.00 \\
\hline \multirow[t]{3}{*}{2.} & Necessity of AAS & & & & \\
\hline & Yes & 19 & 95.00 & 18 & 90.00 \\
\hline & No & 05 & 05.00 & 02 & 10.00 \\
\hline \multirow[t]{5}{*}{3.} & For which weather parameter AAS is essential & & & & \\
\hline & Rainfall & 17 & 85.00 & 18 & 90.00 \\
\hline & Temperature & 13 & 65.00 & 14 & 70.00 \\
\hline & $\mathrm{RH}$ & 07 & 35.00 & 08 & 40.00 \\
\hline & Wind velocity & 03 & 15.00 & 04 & 20.00 \\
\hline \multirow[t]{3}{*}{4.} & Benefit of AAS & & & & \\
\hline & Yes & 17 & 85.00 & 16 & 80.00 \\
\hline & No & 03 & 15.00 & 04 & 20.00 \\
\hline \multirow[t]{5}{*}{5.} & Which way you are benefited from AAS & & & & \\
\hline & Reducing cost during sowing & 18 & 90.00 & 17 & 85.00 \\
\hline & Managing pest and disease & 15 & 75.00 & 15 & 75.00 \\
\hline & Avoid post harvest losses & 07 & 35.00 & 09 & 45.00 \\
\hline & Reducing irrigation charges & 13 & 65.00 & 14 & 70.00 \\
\hline \multirow[t]{5}{*}{6.} & At what stage of crop AAS is essential & & & & \\
\hline & Sowing stage & 17 & 85.00 & 16 & 80.00 \\
\hline & Flowering stage & 08 & 40.00 & 06 & 30.00 \\
\hline & Fruit formation stage & 11 & 55.00 & 14 & 70.00 \\
\hline & Harvesting stage & 13 & 65.00 & 12 & 60.00 \\
\hline \multirow[t]{4}{*}{7.} & Quality of AAS information disseminated & & & & \\
\hline & Good & 15 & 75.00 & 16 & 80.00 \\
\hline & Average & 03 & 15.00 & 03 & 15.00 \\
\hline & Poor & 02 & 10.00 & 01 & 5.00 \\
\hline \multirow[t]{5}{*}{8.} & Frequency of forecasting & & & & \\
\hline & Daily & 03 & 15.00 & 3 & 15.00 \\
\hline & Weekly & 01 & 5.00 & 01 & 5.00 \\
\hline & Bi-weekly & 16 & 80.00 & 16 & 80.00 \\
\hline & Monthly & 00 & 00.00 & 00 & 00.00 \\
\hline \multirow[t]{4}{*}{9.} & Willingness for pay based services & & & & \\
\hline & Yes & 09 & 45 & 08 & 40 \\
\hline & No & 10 & 50 & 11 & 55 \\
\hline & Undecided & 01 & 05 & 01 & 05 \\
\hline \multirow[t]{3}{*}{10.} & Overall satisfaction about AAS & & & & \\
\hline & Yes & 17 & 85.00 & 18 & 90.00 \\
\hline & No & 03 & 15.00 & 02 & 10.00 \\
\hline
\end{tabular}

Source: Field survey data. 
Table 4: Probit model for determining farmers WTP in Vijayapura and Anantapur centre

\begin{tabular}{llllllll}
\hline Variable & \multicolumn{3}{c}{ Vijayapura centre } & & \multicolumn{3}{c}{ Anantapur centre } \\
\cline { 2 - 3 } & $\begin{array}{l}\text { Estimated } \\
\text { co-efficient }\end{array}$ & Std Error & t-ratio & & $\begin{array}{l}\text { Estimated } \\
\text { co-efficient }\end{array}$ & Std Error & t-ratio \\
\hline Constant & 1.760 & 1.060 & 1.660 & & -2.6800 & 2.3480 & -1.1413 \\
Age & 0.055 & 0.032 & 1.718 & & 0.0030 & 0.0350 & 0.0857 \\
Gender & 0.022 & 0.1712 & 0.127 & & -0.0123 & 0.0165 & -0.7432 \\
Family size & 0.002 & 0.002 & 1.285 & & 0.0575 & 0.2814 & 0.2043 \\
Farming experience & -0.047 & 0.022 & $-2.136^{* *}$ & -0.1740 & 0.0538 & $-3.2342^{* *}$ \\
Education level & 0.012 & 0.016 & 0.743 & & 0.0002 & 0.0001 & $2.0596^{* *}$ \\
Land holding size & 0.448 & 0.132 & $3.385^{* *}$ & & 0.2525 & 06015 & 0.4198 \\
Income level & 0.218 & 0.094 & $2.319^{* *}$ & 0.2520 & 0.6017 & 0.4188 \\
\hline
\end{tabular}

Note: Vijayapura -**Significant at $0.05 \%$ level, $\mathrm{df}=7, \mathrm{p}$-value $=0.000$, Chi-squared $=126.35$

Anantapur $-* *$ Significant at $0.05 \%$ level, $\mathrm{df}=7, \mathrm{p}$-value $=0.0000$, chi-square $=75.674$

Table 5: Impact of AAS on crop productivity and economics of cropping systems

\begin{tabular}{|c|c|c|c|c|c|c|c|c|c|c|}
\hline \multirow[t]{2}{*}{ Crops } & \multicolumn{4}{|c|}{ AAS farmers } & \multicolumn{4}{|c|}{ Non-AAS farmers } & \multirow{2}{*}{$\begin{array}{l}\text { Additional } \\
\text { income to } \\
\text { AAS } \\
\text { farmers }\end{array}$} & \multirow{2}{*}{$\begin{array}{l}\% \\
\text { change } \\
\text { over } \\
\text { non- AAS }\end{array}$} \\
\hline & $\begin{array}{r}\mathrm{COC}^{1} \\
\mathrm{ha}^{-1}\end{array}$ & $\begin{array}{r}\text { Yields } \\
\left(\mathrm{q} \mathrm{ha}^{-1}\right)\end{array}$ & $\begin{array}{r}\text { Returns }^{1} \\
\mathrm{ha}^{-1}\end{array}$ & $\begin{array}{l}\mathrm{B}: \mathrm{C} \\
\text { ratio }\end{array}$ & $\begin{array}{r}\mathrm{COC}^{1} \\
\mathrm{ha}^{-1}\end{array}$ & $\begin{array}{r}\text { Yields } \\
\left(\mathrm{q} \mathrm{ha}^{-1}\right)\end{array}$ & $\begin{array}{r}\text { Returns }^{1} \\
\text { ha }^{-1}\end{array}$ & $\begin{array}{l}\mathrm{B}: \mathrm{C} \\
\text { ratio }\end{array}$ & & \\
\hline Maize & 17535 & 25 & 17865 & 1.99 & 21192 & 28 & 13400 & 1.80 & 4465 & 33 \\
\hline Rabi Sorghum & 8696 & 8 & 10125 & 2.12 & 10154 & 9 & 9046 & 1.89 & 1079 & 12 \\
\hline Sunflower & 13535 & 8.8 & 15625 & 2.08 & 14632 & 8 & 12268 & 1.85 & 3357 & 27 \\
\hline Bajra & 8330 & 10 & 10220 & 2.22 & 8110 & 9 & 8740 & 2.07 & 1480 & 17 \\
\hline Groundnut & 18922 & 10 & 25778 & 2.36 & 20135 & 8.5 & 21245 & 2.15 & 4533 & 21 \\
\hline $\begin{array}{l}\text { Castor }+ \\
\text { Redgram }\end{array}$ & 17635 & $8+2.5$ & 19765 & 2.09 & 18420 & $6+3$ & 16130 & 1.95 & 3635 & 23 \\
\hline
\end{tabular}

Source: Field survey data.

compared to non-adopted farmers. Higher crop yields and net returns of AAS farmers as compared to non-AAS farmers were attributed to timely adoption of AAS and better crop management practices like timely sowing, selection of improved crop cultivars, life saving irrigation and management of pest and disease under climatic variability conditions.

\section{REFERENCES}

Ananta-Vashisth, Singh, R., Das, D.K. and Baloda, R. (2013). Weather based agromet advisories for enhancing the production and income of the farmers under changing climate scenario. Int. J. Agric. Food Sci. Tech., 9: 847850 .

Bal, S.K. and Minhas, P.S. (2017) Atmospheric Stressors: Challenges and Coping Strategies. In: P.S. Minhas et al. (eds) Abiotic Stress Management for Resilient Agriculture. Springer Nature Singapore Pte. Ltd., pp. 950.

Chaudhari, J.N., Zagada, M.V., Mahadkar, U.V. and Talathi, M.S. (2010). Assessment of weather based agromet advisoriesin high rainfall zone of Konkan in Maharashtra. In: Proc. of the Nation Seminaron "Agrometeorological Services for Farmers" held at Anand Agricultural University, Gujarat during 10-13 November, 2008. pp.172-177.

Dhamodaran, T. and Vasanth Kumar, J. (2001). Relationship between selected characteristics of registered sugarcane growers and their extent of adoption of improved sugarcane cultivation practices. J. Extn. Edu., 12(2): 3138-3143. 
Dhanya, P. and Ramachandran, A. (2016). Farmers' perceptions of climate change and the proposed agriculture adaptation strategies in a semi-arid region of south India. J. Integra. Environ. Sci., 13(1): 1-18.

Gadgil, S. (1989). Monsoon variability and its relationship with agricultural strategies. Paper presented at International symposium on climate variability and food security in developing countries. Feb 5-7, 1987, New Delhi, India. pp. 249-267.

Maddison, D. (2006). The perception and adaptation to climate change in Africa. CEEPA. Centre for Environmental Economics and Policy inAfrica. Pretoria, South Africa: University of Pretoria. Discussion Paper No. 10.

MadhaviLata, A.G., Sreenivas, K., Vijaya Lakshmi. and Raji Reddy, D. (2009). ISPRS Archives XXXVIII- 8/W3 Workshop Proceedings: Impact of climate change on agriculture. pp. 203-206.

Prasad Rao, G.S.L.H.V. and Manikandan, N. (2008). Economic impact of agrometeorological advisory services over central zone of Kerala. J. Agrometeorol., (SI): 230-234.

Preethi, Chandrasekhar, S., Vaster, Sunitha, A.B. and Manjula, C.N. (2013). A comparative studyon perception of agromet advisory service (AAS) towards climate change. Int. J. Eng. Manage. Sci., 4(3): 357-360.
Rajegowda, M.B., Janardhanagowda, N.A., Jagadeesha, N. and Ravindrababu, B.T. (2008). Influence of agromet advisory services on economic impact of crops. $J$. Agrometeorol., 10: 215-218.

Ramachandrappa, B.K., Thimmegowda, M.N., Krishnamurthy, R., Srikanth Babu, P.N., Savitha, M.S., Srinivasarao, Ch., Gopinath, K. A. and Ravindra Chary, G. (2018). Usefulness and impact of Agromet Advisory Services in eastern dryzone of Karnataka. Indian J. Dryland Agric. Res. Dev., 33(1): 32-36.

Rathore, L.S., Singh, K.K. and Gupta, A. (2003). National Centre for Medium Range Weather Forecasting: Activities, current status and future plans, In: National Seminar on Agrometeorology in the new millennium: Prospectives and Challenges. October, 20-31, 2003, PAU Ludhiana. Souvenir, pp. 141-147.

Vernon, R. (1994). Agriculture, Environment, Climate and Health: Sustainable Development in the 21 st Century, University of Minnesota Press, Minneapolis. pp. 358379.

Vijay Kumar, P., Subba Rao, A.V.M., Sarath Chandran, M.A., Venkatesh,H., Rao, V.U.M. and Srinivas Rao, Ch. (2017). Micro-level Agromet Advisory Services using block level weather forecast-Anew concept based approach. Curr. Sci., 112(2): 227-228. 